\title{
Adiponectin: a manifold therapeutic target for metabolic syndrome, diabetes, and coronary disease?
}

\author{
Enrique Z Fisman ${ }^{1,2^{*}}$ and Alexander Tenenbaum ${ }^{1,2,3}$
}

\begin{abstract}
Adiponectin is the most abundant peptide secreted by adipocytes, being a key component in the interrelationship between adiposity, insulin resistance and inflammation. Central obesity accompanied by insulin resistance is a key factor in the development of metabolic syndrome (MS) and future macrovascular complications. Moreover, the remarkable correlation between coronary artery disease (CAD) and alterations in glucose metabolism has raised the likelihood that atherosclerosis and type 2 diabetes mellitus (T2DM) may share a common biological background. We summarize here the current knowledge about the influence of adiponectin on insulin sensitivity and endothelial function, discussing its forthcoming prospects and potential role as a therapeutic target for MS, T2DM, and cardiovascular disease. Adiponectin is present in the circulation as a dimer, trimer or protein complex of high molecular weight hexamers, $>400 \mathrm{kDa}$. AdipoR1 and AdipoR2 are its major receptors in vivo mediating the metabolic actions. Adiponectin stimulates phosphorylation and AMP (adenosin mono phosphate) kinase activation, exerting direct effects on vascular endothelium, diminishing the inflammatory response to mechanical injury and enhancing endothelium protection in cases of apolipoprotein E deficiency. Hypoadiponectinemia is consistently associated with obesity, MS, atherosclerosis, CAD, T2DM. Lifestyle correction helps to favorably modify plasma adiponectin levels. Low adiponectinemia in obese patients is raised via continued weight loss programs in both diabetic and nondiabetic individuals and is also accompanied by reductions in pro-inflammatory factors. Diet modifications, like intake of fish, omega-3 supplementation, adherence to a Mediterranean dietary pattern and coffee consumption also increase adiponectin levels. Antidiabetic and cardiovascular pharmacological agents, like glitazones, glimepiride, angiotensin converting enzyme inhibitors and angiotensin receptor blockers are also able to improve adiponectin concentration. Fibric acid derivatives, like bezafibrate and fenofibrate, have been reported to enhance adiponectin levels as well. T-cadherin, a membrane-associated adiponectin-binding protein lacking intracellular domain seems to be a main mediator of the antiatherogenic adiponectin actions. The finding of novel pharmacologic agents proficient to improve adiponectin plasma levels should be target of exhaustive research. Interesting future approaches could be the development of adiponectin-targeted drugs chemically designed to induce the activaton of its receptors and/or postreceptor signaling pathways, or the development of specific adiponectin agonists.
\end{abstract}

Keywords: Adipokines, Adiponectin, Atherosclerosis, Coronary artery disease, Diabetes mellitus, Metabolic syndrome, Obesity, T-cadherin

\footnotetext{
* Correspondence: zfisman@post.tau.ac.il

'Sackler Faculty of Medicine, Tel Aviv University, Tel Aviv 69978, Israel

${ }^{2}$ Cardiovascular Diabetology Research Foundation, Holon 58484, Israel

Full list of author information is available at the end of the article
}

\section{Biomed Central}

(c) 2014 Fisman and Tenenbaum; licensee BioMed Central Ltd. This is an Open Access article distributed under the terms of the Creative Commons Attribution License (http://creativecommons.org/licenses/by/4.0), which permits unrestricted use, distribution, and reproduction in any medium, provided the original work is properly credited. The Creative Commons Public Domain Dedication waiver (http://creativecommons.org/publicdomain/zero/1.0/) applies to the data made available in this article, unless otherwise stated. 


\section{Background}

The classical view of adipose tissue as just a passive reservoir for energy storage has radically changed. Two types of adipose tissue are found in mammals, brown and white, each of them with different physiological roles. Brown adipose tissue has specialized functions in thermogenesis through oxidation of fatty acids due to the presence of its specific uncoupling protein (UCP1), which uncouples thermogenic oxidative phosphorylation [1]. Instead, white adipose tissue stores energy in the form of triglycerides and, in situations of energy deficit such as fasting, supplies fatty acids to the circulation.

Thus, white adipose tissue is nowadays perceived as an important organ involved in energy homeostasis and body weight control. Besides its function as an energy reservoir, it plays a key role as an organ secreting numerous bioactive molecules collectively called adipokines or adipocytokines [2]; the first term will be used along the present review. The number of identified adipokines is permanently increasing, as well as their potential clinical diagnostic and prognostic value. These adipokines include mainly adiponectin [2-5], leptin [5], tumor necrosis factor (TNF) alpha [6,7], osteoprotegerin [8] interleukin 6 (IL-6) [9], resistin [10], interleukin 1 (IL-1) $[11,12]$, apelin [13], visfatin [14], monocyte chemotactic protein-1 (MCP-1) $[15,16]$, plasminogen activator inhibitor1 (PAI-1) [17], retinol binding protein 4 (RBP4) [18] and several others.

The adipokines are involved in the regulation of body fat accumulation, adipose tissue development, energy metabolism and control of food intake, and play also a dominant role in the pathophysiology of several metabolic disorders [2-6]. Namely, an abnormal regulation in adipokines production will facilitate a biochemical imbalance potentially leading to the development of various ailments and diseases, mainly obesity, insulin resistance (IR) and atherosclerosis, among others [2,10,19]. It should be pinpointed that not all fatty deposits behave according to the same pathophysiological pattern $[20,21]$. In particular, it has been shown that visceral fat deposits are more metabolically active than their subcutaneous homologues, being particularly involved in the development of diseases associated with obesity, such as the metabolic syndrome (MS), type 2 diabetes mellitus (T2DM) and coronary artery disease (CAD) [21].

Adiponectin is the most abundant peptide secreted by adipocytes $[3,22]$, being a key component in the interrelationship between adiposity, insulin resistance and inflammation [22]. Central obesity accompanied by insulin resistance is a key factor in the development of MS and future macrovascular complications [23]. Moreover, the remarkable correlation between $\mathrm{CAD}$ and alterations in glucose metabolism has raised the likelihood that atherosclerosis and T2DM may share a common biological background [24,25]. Large-vessel atherosclerosis can precede the development of diabetes, suggesting that rather than atherosclerosis being a complication of diabetes, both conditions may share similar genetic and acquired characteristics, a "common soil" [26].

In the present review we summarize the current knowledge about the influence of adiponectin on insulin sensitivity and endothelial function, discussing its forthcoming prospects and potential role as a manifold therapeutic target for MS, diabetes, and cardiovascular disease.

\section{Genetics, structure and circulating levels}

Several studies have revealed a moderate to high estimate of heritability (30-70\%) for plasma adiponectin levels, which are influenced by the interplay of several genes [27-30]. A meta-analysis of genome-wide association studies performed in nearly 40000 individuals in order to identify genes associated with adiponectin levels, revealed 8 loci and confirmed other 2 previously reported loci [31]. One of the main loci seems to be on chromosome 3q27, which contains a susceptibility locus for T2DM and MS [32]. Reduced adiponectin levels can be caused by genetic factors, such as the single nucleotide polymorphism (SNP) 276 in the adiponectin gene itself [33].

Analyses of SNP and mutations in the adiponectin gene have suggested a relationship between adiponectin and glucose metabolism diseases. For instance, SNP at position 94 associates closely with T2DM, as do SNP45 and SNP276 [34,35], and SNP rs266729 was found to be significantly associated with higher odds of CAD [33]. Unfavorable effects of the AdipoQ $45 \mathrm{~T} / \mathrm{G}$ SNP on lipid profile and glucose metabolism have also been described [36]. Moreover, the latter polymorphism is also strongly correlated with CAD in T2DM subjects [37]. Interestingly, it has been suggested that primary genetic lesions that lower adiponectin levels may result in hypertension [38]; decreased circulating adiponectin and hypertension correlated significantly with the I164T polymorphism [39].

Adiponectin is a protein consisting of 244 aminoacids displaying structural similarities to collagen and TNFalpha, and is mostly located in adipocytes. Adiponectin was independently identified by several research groups using different techniques, receiving different names like ACRP30, AdipoQ and apM1 [40-42]. Adiponectin is a protein of $30 \mathrm{kDa}$ present in the circulation as a dimer, trimer or as a protein complex of high molecular weight (HMW) hexamers, $>400 \mathrm{kDa}$, in which the oligomers control the biological activity of the protein [43]. The higher order structures include also low-molecular weight (LMW) hexamers of $180 \mathrm{kDa}$. Adiponectin can exist in plasma in its complete form or in globular fragments; the first appears to be the most common form. It 
circulates at physiological concentrations that represent about $0.05 \%$ of all plasma proteins [22].

The normal circulating values were initially set at $5-30 \mu \mathrm{g} / \mathrm{ml}$ [42], albeit subsequent investigations reported a much narrower range $-5-10 \mu \mathrm{g} / \mathrm{ml}-[44,45]$. It should be pinpointed that ethnic and gender differences are present; values are higher in Caucasians than in Indo-Asians [46] and in women than in men [44], albeit significant gender differences in adiponectin concentrations were not observed in a Sudanese population [47]. Significantly lower values have been reported in women with gestational diabetes [48] and during menopause [49]. Concentrations are at lower normal limits in obese subjects [44], and reduced in MS, both in humans [50] and in experimental animal models [51].

Importantly, adiponectin values are also systematically lower in diabetics compared to non-diabetics, no matter to what heart failure staging class they belong [52]. An exception to the general rule linking increased adiponectin levels with a better outcome seems to be nonischemic cardiomyopathy, in which despite of its high peripheral concentrations, it does not show cardioprotective effects [53].

\section{General bioactivity}

Mice studies have confirmed that adiponectin receptors AdipoR1 and AdipoR2 are its major receptors in vivo [54,55] mediating the metabolic actions. These effects are also dependent on specific tissues, with muscular AdipoR1 involved in stimulating adenosin mono phosphate (AMP) activated protein kinase, while hepatic AdipoR2 is involved mainly in activation of the peroxisome proliferator activated receptor (PPAR) gamma. Both AdipoR1 and AdipoR2 serve as receptors for globular and full-length adiponectin and mediate also increased fatty-acid oxidation and glucose uptake $[55,56]$.

Adiponectin, both in its globular and HMW forms, stimulates phosphorylation and AMP kinase activation in skeletal muscle. Anyway, the use of full-length adiponectin produced by mammalian cells suggests that the liver and not muscle is the primary site of adiponectin bioactivity [57]. In addition to AMP kinase activation, adiponectin induces carboxylase acetyl-coenzyme A phosphorylation, glucose uptake, nitric oxide synthesis, lactate production in myocytes, and reduced liver production of molecules involved in gluconeogenesis. These effects seem responsible for the lowering of glucose levels in vivo, via glucose utilization and fatty-acid oxidation by activating AMP-activated protein kinase [58]. T-cadherin, a membraneassociated adiponectin-binding protein localized in vascular smooth muscle cells and endothelial cells, seems to be the mediator of adiponectin activity [59].

In a mammalian expression system, full-length adiponectin is produced and secreted both as LMW and HMW complexes. Interestingly, its administration to normal weight or obese-diabetic mice results in a decreased serum glucose $[57,60]$. The effect of adiponectin on the liver requires hydroxylation and glycosylation of residues within the collagenous domain of adiponectin [61]. This finding may explain why studies employing the globular form (lacking the collagenous domain) or the bacterially produced fulllength form (lacking post-translational modifications in the collagenous domain) do not affect hepatic glucose metabolism or insulin sensitivity [60]. It has been shown that only HMW adiponectin decreases after a glucose load, suggesting that the HMW form of adiponectin is prone to be affected more rapidly than its LMW or mediummolecular weight counterparts. The mechanism remains unclear; possibly explanations may include decreased secretion of HMW adiponectin by adipocytes, augmented clearance of HMW adiponectin from the circulation, increased metabolism of HMW adiponectin, or a combination of these facts [62]. Adiponectin is very stable in vivo compared with other adipokines, since its half-life is very much longer, ranging from 2.5 [63] to 14 hours [64].

Another important point that should be mentioned is that serum adiponectin is inversely related to body fat mass and to the degree of insulin resistance. Its concentration is particularly low in adults with T2DM or CAD. It is accepted, therefore, that adiponectin ameliorates sensitivity to insulin and contributes to cardiovascular protection [65-67]. Low circulating levels, particularly of the HMW component $[68,69]$, are also a strong risk marker for the development of the MS.

Hypoadiponectinemia is also associated with elevated intramyocellular and intrahepatic lipid content, as seen in non-alcoholic fatty liver and non-alcoholic steatohepatitis, additional indicators of dyslipidemia not currently included as risk factors for the MS [70-72], showing an inverse relationship with vascular endothelial growth factor levels in some inflammatory settings [73].

\section{Adiponectin and insulin sensitivity}

Adiponectin increases the sensitivity to insulin through several mechanisms. AdipoR1 and AdipoR2 are transmembrane receptors, whose carboxyl terminal group (C-terminal) is located outside the membrane, and the amino terminal group (N-terminal) inside [74]. When adiponectin attaches to its receptor it activates AMP kinase [19,67], promoting so glucose uptake by muscles via intracellular translocation of the GLUT4 transporters. Simultaneously, it hampers gluconeogenesis by inhibiting the hepatic enzyme phosphoenolpyruvate carboxylase, inhibits the synthesis of fatty acids and stimulates their oxidation [22,67].

Independently, adiponectin acts as an agonist of the peroxisome proliferator activated receptor (PPAR) gamma leading to additional uptake of plasmatic glucose [67]. 
In this context, the adiponectin-resistin index provides a good indicator for an increased risk of future development of T2DM and MS [75]. Finally, adiponectin enhances insulin sensitivity by increasing hepatic insulin receptor substrate 2 (IRS-2) expression via a macrophagederived IL-6-dependent pathway [66]. Thus, these multiple pathways confer to adiponectin a key role in ensuring an effective protection against the development of insulin resistance (IR).

\section{Adiponectin and endothelial function}

It has been shown that adiponectin exerts direct effects on vascular endothelium, diminishing the inflammatory response to mechanical injury and enhancing endothelium protection in cases of apolipoprotein E deficiency $[43,76,77]$. Regarding other lipids, cross-sectional studies showed, after adjusting for gender and adiposity, that adiponectin levels present a inverse correlation with triglycerides [78], while they are directly correlated with HDL-cholesterol [79].

It has been found that adiponectin plasma concentrations are lower in individuals with CAD compared to age- and obesity-matched controls [80] and that individuals with adiponectin levels under $4 \mu \mathrm{g} / \mathrm{ml}$ were at increased risk of CAD and presented more factors for MS [81]. Conversely, while prospectively evaluating men without $\mathrm{CAD}$, it was found after a 6 year-follow up that individuals in the highest percentile of plasma adiponectin were at a lower risk of MI, compared with those in the lowest percentile [82]. Adiponectin levels are also decreased in people with hypertension, regardless the presence of insulin resistance [83]. These subjects are characterized by a decreased endothelium-dependent vasodilation, which could be one of the mechanisms involved in central obesity-associated hypertension [84].

It is well established that adiponectin has an antiatherosclerotic effect via inhibition of adhesion molecules production, such as vascular cell adhesion protein 1 (VCAM-1) and selectin E $[85,86]$. The adiponectinmediated suppression of nuclear factor $\mathrm{kB}$, could be an important molecular mechanism for inhibiting monocytes adhesion to endothelial cells [86]. Immunohistochemistry studies show that adiponectin is not incorporated into the normal and intact vessel wall, while it presents a marked adherence to previously damaged vessel walls, like those mechanically injured by balloon catheters [87], and adiponectin may also act as a modulator for macrophage-tofoam cell transformation, slowing or inhibiting the process [88]. Moreover, experimental and clinical investigations indicate that adiponectin promotes endothelial repair and angiogenesis by increasing the number and function of endothelial progenitor cells (EPCs) [89-91]. This EPCsmediated endothelial repair involves several stages, beginning with mobilization of EPCs from bone marrow or spleen into the bloodstream, followed by recruitment and adhesion of EPCs to the injured blood vessel wall, and finally, differentiation and tubule formation. Thus, adiponectin modulates almost every step of endothelial repair via EPCs [92,93]. A schematic representation of the multiple detrimental biological and clinical effects of hypoadiponectinemia is depicted in Figure 1.

\section{Current and forthcoming therapeutic prospects}

Adiponectin levels may be negatively influenced by lifestyle, such as sedentarism, a high-fat diet causing obesity, or excessive smoking [94]. This influence can be reversed; lifestyle correction helps to favorably modify plasma adiponectin levels. Low adiponectinemia in obese patients was raised via continued weight loss programs in both diabetic and nondiabetic individuals [95,96], in obese adolescents [97] and was also accompanied by reductions in pro-inflammatory factors like IL-6, leptin and TNF alpha [98]. Moreover, increased adiponectin levels were already apparent after 1 week (two to three bouts) of moderately intense aerobic exercise, in some cases up to $260 \%$ [99]. Regarding diet modifications, several studies reported that daily intake of fish or omega-3 supplementation increased adiponectin levels by amounts ranging from 14 to $60 \%$ [100]. Furthermore, adherence to a Mediterranean dietary pattern showed excellent results in T2DM women [101]. Coffee consumption has also shown beneficial effects on adiponectin levels [102].

Unfortunately, adiponectin itself cannot be administered orally since its main component is a protein which is dissolved by the digestive system enzymes, being thus unable to reach the bloodstream. On the other hand, adiponectin levels may be pharmacologically modified. In this context, it has been found that antidiabetic treatment with either insulin or metformin in experimental models - albeit not able to improve adiponectin induced vasodilation and endothelial function - inhibits both the development of hypoadiponectinemia and the downregulation of the adaptor protein APPL1 in mesenteric resistance arteries [103]. Moreover, adiponectin concentrations increase after pioglitazone therapy in subjects with impaired glucose tolerance; glitazones also improve adiponectin levels in normal, obese, and T2DM subjects [104]. It should be highlighted that baseline adiponectin levels do not predict the response to glitazones [105]. Anyway, the use of glitazones to increase adiponectin is discouraged due to the potential adverse cardiovascular effects of these drugs, like heart failure or stroke [106], especially in the case of rosiglitazone [107]. The sulfonylurea glimepiride yields also positive effects on adiponectin, particularly in elderly T2DM patients [108].

Bezafibrate, a fibric acid derivative known for its capability to attenuate the progression of IR in CAD patients [109] and the declining of beta cells function in T2DM 


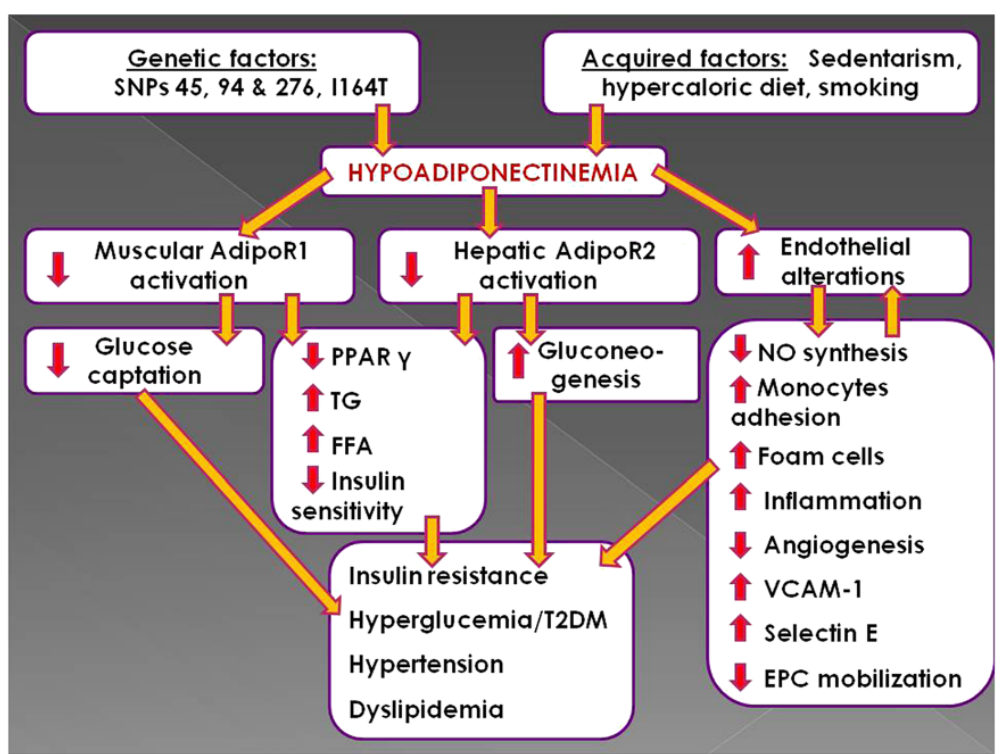

Figure 1 Schematic depiction of the clinical outcomes of hypoadiponectinemia. Hypoadiponectinemia leads to diminished adiponectin receptors activation accompanied by increased endothelial alterations. These factors put forth several biochemical chain reactions exerting detrimental consequences via multiple pathways. These chain reactions may act reciprocally, finally conducting to serious cardiometabolic derangement.

[110] has been reported to enhance adiponectin levels, partly acting through PPAR alpha stimulation [111]. Similar properties were reported for fenofibrate [111,112].

Cardiovascular drugs, as renin-angiotensin system blocking agents and angiotensin converting enzyme inhibitors significantly increase adiponectin levels and improve insulin sensitivity without affecting the degree of body adiposity [113-115]. For instance, telmisartan upregulates the expression of myocardial adiponectin, its receptor adipoR2, as well as GLUT4. Simultaneously, it also induces a protective role on the vascular system by upregulating the expression of adipoR1 and downregulating the expression of MCP-1 and nuclear factor kappa B (NF-kB) in the abdominal aorta in experimental animal models [116]. Coadministration of candesartan and pioglitazone during 6 months to hypertensive patients with T2DM significantly improved the baseline values of HMW adiponectin [117]. A potential mechanism for renin angiotensin system blocking agents to affect adiponectin levels seems to be promotion of adipogenic differentiation of preadipocytes [118] via PPAR gamma activity [119].

Attempts to increase adiponectin were also performed with nutraceutical agents like the herb derivatives astragaloside II and isoastragaloside, with satisfactory results in rodents $[120,121]$. In contrast, the use of purified allicin (the active ingredient in garlic) was unsuccessful [122].

With the increasing prevalence of T2DM and obesity, new technologies are developed to more easily monitor adiponectin levels or its potential surrogates. Currently, the concentration of total adiponectin maybe obtained by a using a commercially available human adiponectin radioimmunoassay kit [123] or enzyme-linked immunosorbent assays [124]. It has been shown that salivary $\mathrm{pH}$ is directly and significantly correlated to plasma adiponectin levels in premenopausal and menopausal women [125]. Should this condition be confirmed for other populations, salivary $\mathrm{pH}$ determination could represent an additional noninvasive, simple, and inexpensive surrogate for adiponectin assessment $[126,127]$. Urinary adiponectin can also be measured, and an increased concentration is associated with microalbuminuria and boteh micro- and macrovascular complications [128]. Anyway, laboratory methods for adiponectin measurement still require a more appropriate standardization, and this is also applicable to the determination of ideally therapeutic adiponectin levels for given clinical settings. It should be mentioned that excessively high concentrations may be undesirable; it has been reported that increased serum adiponectin and HOMA-IR could be associated with an augmented risk for the presence and development of cardiac autonomic neuropathy [129].

\section{Conclusions}

As highlighted above, both functional and genetic studies on adiponectin strongly depict it as a key adipokine. Reduced adiponectin levels seem to be not just a mere biomarker of ailment, but play a causal role in the development of IR, MS, T2DM, hypertension, dyslipidemia and atherosclerosis $[33,130]$. On the other hand, favorable effects of a given adipokine on either diabetes or 
atherosclerosis predict similar effects on the other [131]. Hence, taking into consideration the high world prevalence of obesity, MS, T2DM and CAD, the possibility of a defined and unique therapeutic target to simultaneously combat their development becomes increasingly important [95].

Since adiponectin levels are consistently inversely correlated with each of these ailments, the finding of pharmacologic agents proficient to improve its plasma levels should be target of exhaustive research. An interesting approach could be the development of adiponectin-targeted drugs chemically designed to induce the activaton of its receptors and/or postreceptor signaling pathways. Such a move may also be able to reverse "adiponectin resistance", which has been observed in both experimental and human research models [121,132]. Moreover, orally active AdipoR1 and AdipoR2 agonists were already satisfactorily used in rodent models [133]. T-cadherin, a membraneassociated adiponectin-binding protein lacking intracellular domain $[134,135]$ seems to be a main mediator of the antiatherogenic adiponectin actions, and maybe a component of insulin granules [136]. Both adiponectin and $\mathrm{T}$-cadherin were found to be inversely associated with human aortic and coronary atherosclerosis [59], and it appears that a majority of the whole body adiponectin is conveyed to cardiovascular tissues by T-cadherin $[134,137,138]$. T-cadherin seems to be a clue novel signaling pathway at the crossroads of vascular and metabolic disorders $[139,140]$. Hence, adiponectin represents in fact a multilayered therapeutic target for MS, diabetes and CAD. Investigating the intimate biochemical relationship between adiponectin, its receptors AdipoR1 and AdipoR2, and T-cadherin within the cardiovascular system could be a very promising avenue for the development of specific adiponectin agonists.

\footnotetext{
Abbreviations

AMP: Adenosin mono phosphate; AMPK: Adenosine monophosphate-activated protein kinase; CAD: Coronary artery disease; EPCs: Endothelial progenitor cells; FFA: Free fatty acids; HMW: High molecular weight; IR: Insulin resistance; LMW: Low molecular weight; MCP-1: monocyte chemotactic protein-1; MS: metabolic syndrome; NO: Nitric oxide; PPAR: Peroxisome proliferator activated receptor; SNP: Single nucleotide polymorphism; TG: Triglycerides; TNF: Tumor necrosis factor; T2DM: Type 2 diabetes mellitus; VCAM-1: Vascular cell adhesion protein 1
}

\section{Competing interests}

The authors declare that they have no competing interests.

\section{Authors' contributions}

Enrique Z Fisman and Alexander Tenenbaum have equally contributed in the conception and drafting of the manuscript. Both authors read and approved the final manuscript.

\section{Acknowledgements}

This work was supported in part by the Cardiovascular Diabetology Research Foundation (RA 58-040-684-1), Holon, Israel.

\section{Author details}

${ }^{1}$ Sackler Faculty of Medicine, Tel Aviv University, Tel Aviv 69978, Israel. ${ }^{2}$ Cardiovascular Diabetology Research Foundation, Holon 58484, Israel.

${ }^{3}$ Cardiac Rehabilitation Institute, Sheba Medical Center, Tel Hashomer 52621, Israel.

Received: 23 May 2014 Accepted: 26 May 2014

Published: 23 June 2014

\section{References}

1. Tiraby C, Langin D: Conversion from white to brown adipocytes: a strategy for the control of fat mass? Trends Endocrinol Metab 2003, 14:439-441.

2. Robinson K, Prins J, Venkatesh B: Clinical review: adiponectin biology and its role in inflammation and critical illness. Crit Care 2011, 15:221.

3. Maia-Fernandes T, Roncon-Albuquerque R Jr, Leite-Moreira AF: Cardiovascular actions of adiponectin: pathophysiologic implications. Rev Port Cardiol 2008, 27:1431-1449

4. Sulistyoningrum DC, Gasevic D, Lear SA, Ho J, Mente A, Devlin AM: Total and high molecular weight adiponectin and ethnic-specific differences in adiposity and insulin resistance: a cross-sectional study. Cardiovasc Diabetol 2013, 12:170.

5. Hajer GR, Van Haeften TW, Visseren FL: Adipose tissue dysfunction in obesity, diabetes, and vascular diseases. Eur Heart J 2008, 29:2959-2971.

6. Baars T, Konorza T, Kahlert P, Möhlenkamp S, Erbel R, Heusch G, Kleinbongard $\mathrm{P}$ : Coronary aspirate TNFa reflects saphenous vein bypass graft restenosis risk in diabetic patients. Cardiovasc Diabetol 2013, 12:12.

7. Kato M, Kakehi R, Soma Gl, Gatanaga T, Mizuno D: Anti-tumour therapy by induction of endogenous tumour necrosis factor. Lancet 1985, 2 (8449):270.

8. Ghaffari S, Yaghoubi A, Baghernejad R, Sepehrvand N, Sokhanvar S, Haghjou AG: The value of serum osteoprotegerin levels in patients with angina like chest pain undergoing diagnostic coronary angiography. Cardiol J 2013, 20:261-267.

9. Fisman EZ, Benderly M, Esper RJ, Behar S, Boyko V, Adler Y, Tanne D, Matas Z, Tenenbaum A: Interleukin- 6 and the risk of future cardiovascular events in patients with angina pectoris and/or healed myocardial infarction. Am J Cardiol 2006, 98:14-18.

10. Shuldiner AR, Yang R, Gong DW: Resistin, obesity and insulin resistance - the emerging role of the adipocyte as an endocrine organ. N Engl J Med 2001, 345:1345-1346.

11. Apte RN, Voronov E: Is interleukin-1 a good or bad 'guy' in tumor immunobiology and immunotherapy? Immunol Rev 2008, 222:222-241.

12. Toldo S, Mezzaroma E, O'Brien L, Marchetti C, Seropian IM, Voelkel NF Van Tassell BW, Dinarello CA, Abbate A: Interleukin-18 mediates interleukin-1-induced cardiac dysfunction. Am J Physiol Heart Circ Physiol 2014, 306:H1025-H1031.

13. Szokodi I, Tavi P, Földes G, Voutilainen-Myllylä S, Ilves M, Tokola H, Pikkarainen S, Piuhola J, Rysä J, Tóth M, Ruskoaho H: Apelin, the novel endogenous ligand of the orphan receptor APJ, regulates cardiac contractility. Circ Res 2002, 91:434-440.

14. Hug C, Lodish HF: Medicine. Visfatin: a new adipokine. Science 2005, 307:366-367.

15. Kolattukudy PE, Quach T, Bergese S, Breckenridge S, Hensley J, Altschuld R, Gordillo G, Klenotic S, Orosz C, Parker-Thornburg J: Myocarditis induced by targeted expression of the MCP-1 gene in murine cardiac muscle. Am J Pathol 1998, 152:101-111.

16. Tuñón J, Blanco-Colio L, Cristóbal C, Tarín N, Higueras J, Huelmos A, Alonso J, Egido J, Asensio D, Lorenzo Ó, Mahíllo-Fernández I, Rodríguez-Artalejo F, Farré J, Martín-Ventura JL, López-Bescós L: Usefulness of a combination of monocyte chemoattractant protein-1, galectin-3, and N-terminal probrain natriuretic peptide to predict cardiovascular events in patients with coronary artery disease. Am J Cardio/ 2014, 113:434-440.

17. Boe AE, Eren M, Murphy SB, Kamide CE, Ichimura A, Terry D, McAnally D, Smith LH, Miyata T, Vaughan DE: Plasminogen activator inhibitor-1 antagonist TM5441 attenuates N $\omega$-nitro-L-arginine methyl ester-induced hypertension and vascular senescence. Circulation 2013, 128:2318-2324.

18. Liu Y, Wang D, Li D, Sun R, Xia M: Associations of retinol-binding protein 4 with oxidative stress, inflammatory markers, and metabolic syndrome in a middle-aged and elderly Chinese population. Diabetol Metab Syndr 2014, 6:25. 
19. Yamauchi T, Kadowaki T: Physiological and pathophysiological roles of adiponectin and adiponectin receptors in the integrated regulation of metabolic and cardiovascular diseases. Int J Obes (Lond) 2008, 32(Suppl 7):S13-S18.

20. Moreno-Aliaga MJ, Lorente-Cebrián S, Pérez-Echarri N, Martínez Hernández A: Visfatina, apelina y nuevas moléculas del síndrome metabólico. Rev Esp Obes 2008, 6:205-214.

21. Hamdy O, Porramatikul S, Al-Ozairi E: Metabolic obesity: the paradox between visceral and subcutaneous fat. Curr Diabetes Rev 2006, 2:367-373.

22. Silva TE, Colombo G, Schiavon LL: Adiponectin: A multitasking player in the field of liver diseases. Diabetes Metab 2014, 40:95-107.

23. Tenenbaum A, Motro M, Schwammenthal E, Fisman EZ: Macrovascular complications of metabolic syndrome: an early intervention is imperative. Int J Cardiol 2004, 97:167-172.

24. Fisman EZ, Motro M, Tenenbaum A: Cardiovascular diabetology in the core of a novel interleukins classification: the bad, the good and the aloof. Cardiovasc Diabetol 2003, 2:11.

25. Grundy SM: Obesity, metabolic syndrome, and coronary atherosclerosis. Circulation 2002, 105:2696-2698.

26. Stern MP: Diabetes and cardiovascular disease. The "common soil" hypothesis. Diabetes 1995, 44:369-374.

27. Comuzzie AG, Funahashi T, Sonnenberg G, Martin LJ, Jacob HJ, Black AE, Maas D, Takahashi M, Kihara S, Tanaka S, Matsuzawa Y, Blangero J, Cohen D, Kissebah A: The genetic basis of plasma variation in adiponectin, a global endophenotype for obesity and the metabolic syndrome. J Clin Endocrinol Metab 2001, 86:4321-4325.

28. Vasseur F, Helbecque N, Dina C, Lobbens S, Delannoy V, Gaget S, Boutin P, Vaxillaire M, Leprêtre F, Dupont S, Hara K, Clément K, Bihain B, Kadowaki T, Froguel $P$ : Singlenucleotide polymorphism haplotypes in the both proximal promoter and exon 3 of the APM1 gene modulate adipocyte-secreted adiponectin hormone levels and contribute to the genetic risk for type 2 diabetes in French Caucasians. Hum Mol Genet 2002, 11:2607-2614.

29. Cesari M, Narkiewicz K, De Toni R, Aldighieri E, Williams CJ, Rossi GP: Heritability of plasma adiponectin levels and body mass index in twins. $J$ Clin Endocrinol Metab 2007, 92:3082-3088.

30. Liu PH, Jiang YD, Chen WJ, Chang CC, Lee TC, Sun HS, Chuang LM: Genetic and environmental influences on adiponectin, leptin, and BMI among adolescents in Taiwan: a multivariate twin/sibling analysis. Twin Res Hum Genet 2008, 11:495-504.

31. Dastani Z, Hivert MF, Timpson N, Perry JR, Yuan X, Scott RA, Henneman P, Heid IM, Kizer JR, Lyytikäinen LP, Fuchsberger C, Tanaka T, Morris AP, Small K, Isaacs A, Beekman M, Coassin S, Lohman K, Qi L, Kanoni S, Pankow JS, Uh HW, Wu Y, Bidulescu A, Rasmussen-Torvik LJ, Greenwood CM, Ladouceur M, Grimsby J, Manning AK, CT L: Novel loci for adiponectin levels and their influence on type 2 diabetes and metabolic traits: a multi-ethnic meta-analysis of 45,891 individuals. PLoS Genet 2012, 8(3):e1002607.

32. Kissebah AH, Sonnenberg GE, Myklebust J, Goldstein M, Broman K, James RG, Marks JA, Krakower GR, Jacob HJ, Weber J, Martin L, Blangero J, Comuzzie AG: Quantitative trait loci on chromosomes 3 and 17 influence phenotypes of the metabolic syndrome. Proc Natl Acad Sci U S A 2000, 97:14478-14483.

33. Tong $G$, Wang $N$, Leng J, Tong $X$, Shen $Y$, Yang J, Ye X, Zhou L, Zhou Y: Common variants in adiponectin gene are associated with coronary artery disease and angiographical severity of coronary atherosclerosis in type 2 diabetes. Cardiovasc Diabetol 2013, 12:67.

34. Stumvoll M, Tschritter O, Fritsche A, Staiger H, Renn W, Weisser M, Machicao F, Häring $H$ : Association of the T-G polymorphism in adiponectin (exon 2) with obesity and insulin sensitivity: interaction with family history of type 2 diabetes. Diabetes 2002, 51:37-41.

35. Hara K, Boutin P, Mori Y, Tobe K, Dina C, Yasuda K, Yamauchi T, Otabe S, Okada T, Eto K, Kadowaki H, Hagura R, Akanuma Y, Yazaki Y, Nagai R, Taniyama M, Matsubara K, Yoda M, Nakano Y, Tomita M, Kimura S, Ito C, Froguel P, Kadowaki T: Genetic variation in the gene encoding adiponectin is associated with an increased risk of type 2 diabetes in the Japanese population. Diabetes 2002, 51:536-540.

36. Curti ML, Pires MM, Barros CR, Siqueira-Catania A, Rogero MM, Ferreira SR: Associations of the TNF-alpha -308 G/A, IL6-174 G/C and AdipoQ 45 $\mathrm{T} / \mathrm{G}$ polymorphisms with inflammatory and metabolic responses to lifestyle intervention in Brazilians at high cardiometabolic risk. Diabetol Metab Syndr 2012, 4:49

37. Lacquemant C, Froguel P, Lobbens S, Izzo P, Dina C, Ruiz J: The adiponectin gene SNP45 is associated with coronary artery disease in
Type 2 (non-insulindependent) diabetes mellitus. Diabet Med 2004, 21:776-781.

38. Iwashima Y, Katsuya T, Ishikawa K, Ouchi N, Ohishi M, Sugimoto K, Fu Y, Motone M, Yamamoto K, Matsuo A, Ohashi K, Kihara S, Funahashi T, Rakugi H, Matsuzawa Y, Ogihara T: Hypoadiponectinemia is an independent risk factor for hypertension. Hypertension 2004, 43:1318-1323.

39. Ohashi K, Ouchi N, Kihara S, Funahashi T, Nakamura T, Sumitsuji S, Kawamoto T, Matsumoto S, Nagaretani H, Kumada M, Okamoto Y, Nishizawa H, Kishida K, Maeda N, Hiraoka H, Iwashima Y, Ishikawa K, Ohishi M, Katsuya T, Rakugi H, Ogihara T, Matsuzawa Y: Adiponectin I164T mutation is associated with the metabolic syndrome and coronary artery disease. J Am Coll Cardiol 2004, 43:1195-1200.

40. Scherer PE, Williams S, Fogliano M, Baldini G, Lodish HF: A novel serum protein similar to $\mathrm{C1q}$, produced exclusive in adipocytes. J Biol Chem 1995, 270:26746-26749.

41. Hu E, Liang P, Spiegelman BM: AdipoQ is a novel adiposespecific gene dysregulated in obesity. J Biol Chem 1996, 271:10697-10703.

42. Maeda K, Okubo K, Shimomura I, Funahashi T, Matsuzawa Y, Matsubara K: CDNA cloning and expression of a novel adipose specific collagen-like factor, apM1 (AdiPose Most abundant Gene transcript 1). Biochem Biophys Res Commun 1996, 221:286-289.

43. Domínguez Reyes CA: Adiponectina: el tejido adiposo más allá de la reserva inerte de energía. Rev Endocr Nutr 2007, 15:149-155.

44. Silva-Nunes J, Oliveira A, Duarte L, Barradas M, Melão A, Brito M, Veiga L: Factors related with adiponectinemia in obese and normal-weight women and with its variation in weight loss programs. Obes Facts 2013 6:124-133.

45. Arita Y: Paradoxical decrease of an adipose-specific protein, adiponectin, in obesity. Biochem Biophys Res Commun 1999, 257:79-83.

46. Valsamakis G, Chetty R, McTernan PG, Al-Daghri NM, Barnett AH, Kumar S: Fasting serum adiponectin concentration is reduced in Indo-Asian subjects and is related to HDL cholesterol. Diabetes Obes Metab 2003, 5:131-135.

47. Abdelgadir M, Karlsson AF, Berglund L, Berne C: Low serum adiponectin concentrations are associated with insulin sensitivity independent of obesity in Sudanese subjects with type 2 diabetes mellitus. Diabetol Metab Syndr 2013, 5:15

48. Ranheim T, Haugen F, Staff AC, Braekke K, Harsem NK, Drevon CA: Adiponectin is reduced in gestational diabetes mellitus in normal weight women. Acta Obstet Gynecol Scand 2004, 83:341-347.

49. Milewicz A, Zatonska K, Demissie M, Jêdrzejuk D, Dunajska K, llow R, Lwow F: Serum adiponectin concentration and cardiovascular risk factors in climacteric women. Gynecol Endocrinol 2005, 20:68-73.

50. Kim JY, Choi EY, Mun HS, Min PK, Yoon YW, Lee BK, Hong BK, Rim SJ, Kwon HM: Usefulness of metabolic syndrome score in the prediction of angiographic coronary artery disease severity according to the presence of diabetes mellitus: relation with inflammatory markers and adipokines. Cardiovasc Diabetol 2013, 12:140.

51. Leguisamo NM, Lehnen AM, Machado UF, Okamoto MM, Markoski MM, Pinto GH, Schaan BD: GLUT4 content decreases along with insulin resistance and high levels of inflammatory markers in rats with metabolic syndrome. Cardiovasc Diabetol 2012, 11:100.

52. Baldasseroni S, Antenore A, Di Serio C, Orso F, Lonetto G, Bartoli N, Foschini A, Marella A, Pratesi A, Scarantino S, Fumagalli S, Monami M, Mannucci E, Marchionni N, Tarantini F: Adiponectin, diabetes and ischemic heart failure: a challenging relationship. Cardiovasc Diabetol 2012, 11:151.

53. Caselli C, Lionetti V, Cabiati M, Prescimone T, Aquaro GD, Ottaviano V, Bernini F, Mattii L, Del Ry S, Giannessi D: Regional evidence of modulation of cardiac adiponectin level in dilated cardiomyopathy: pilot study in a porcine animal model. Cardiovasc Diabetol 2012, 11:143.

54. Yamauchi T, Nio Y, Maki T, Kobayashi M, Takazawa T, Iwabu M, Okada-Iwabu M, Kawamoto S, Kubota N, Kubota T, Ito Y, Kamon J, Tsuchida A, Kumagai K, Kozono H, Hada Y, Ogata H, Tokuyama K, Tsunoda M, Ide T, Murakami K, Awazawa M, Takamoto I, Froguel P, Hara K, Tobe K, Nagai R, Ueki K, Kadowaki T: Targeted disruption of AdipoR1 and AdipoR2 causes abrogation of adiponectin binding and metabolic actions. Nat Med 2007, 13:332-339.

55. Yamauchi T, Iwabu M, Okada-Iwabu M, Kadowaki T: Adiponectin receptors: a review of their structure, function and how they work. Best Pract Res Clin Endocrinol Metab 2014, 28:15-23. 
56. Kharroubi I, Rasschaert J, Eizirik DL, Cnop M: Expression of adiponectin receptors in pancreatic beta cells. Biochem Biophys Res Commun 2003, 312:1118-1122.

57. Berg AH, Combs T, Du X, Brownlee M, Scherer PE: The adipocyte-secreted protein Acrp30 enhances hepatic insulin action. Nat Med 2001, 7:947-953.

58. Yamuchi T, Kamon J, Minokoshi Y, Ito Y, Waki H, Uchida S, Yamashita S, Noda M, Kita S, Ueki K, Eto K, Akanuma Y, Froguel P, Foufelle F, Ferre P, Carling D, Kimura S, Nagai R, Kahn BB, Kadowaki T: Adiponectin stimulates glucose utilization and fatty-acid oxidation by activating AMP-activated protein kinase. Nat Med 2002, 8:1288-1295.

59. Kostopoulos CG, Spiroglou SG, Varakis JN, Apostolakis E, Papadaki HH: Adiponectin/T-cadherin and apelin/APJ expression in human arteries and periadventitial fat: implication of local adipokine signaling in atherosclerosis? Cardiovasc Pathol 2014, 23:131-138.

60. Trujillo ME, Scherer PE: Adiponectin - journey from an adipocyte secretory protein to biomarker of the metabolic syndrome. J Intern Med 2005, 257:167-175

61. Wang Y, Xu A, Knight C, Xu LY, Cooper GJ: Hydroxylation and glycosylation of the four conserved lysine residues in the collagenous domain of adiponectin. Potential role in the modulation of its insulin-sensitizing activity. J Biol Chem 2002, 277:19521-19529.

62. Ozeki N, Hara K, Yatsuka C, Nakano T, Matsumoto S, Suetsugu M, Nakamachi T, Takebayashi K, Inukai T, Haruki K, Aso Y: Serum high-molecular weight adiponectin decreases abruptly after an oral glucose load in subjects with normal glucose tolerance or impaired fasting glucose, but not those with impaired glucose tolerance or diabetes mellitus. Metabolism 2009, 58:1470-1476.

63. Peake PW, Kriketos AD, Campbell LV, Shen Y, Charlesworth JA: The metabolism of isoforms of human adiponectin: studies in human subjects and in experimental animals. Eur J Endocrinol 2005, 153:409-417.

64. Hoffstedt J, Arvidsson E, Sjölin E, Wåhlén K, Arner P: Adipose tissue adiponectin production and adiponectin serum concentration in human obesity and insulin resistance. J Clin Endocrinol Metab 2004, 89:1391-1396.

65. Díez JJ, Iglesias P: The role of the novel adipocyte-derived hormone adiponectin in human disease. Eur J Endocrinol 2003, 148:293-300.

66. Awazawa M, Ueki K, Inabe K, Yamauchi T, Kubota N, Kaneko K, Kobayashi M, Iwane A, Sasako T, Okazaki Y, Ohsugi M, Takamoto I, Yamashita S, Asahara H, Akira S, Kasuga M, Kadowaki T: Adiponectin enhances insulin sensitivity by increasing hepatic IRS-2 expression via a macrophage-derived IL-6-dependent pathway. Cell Metab 2011, 13:401-412.

67. Kadowaki T, Yamauchi T, Kubota N, Hara K, Ueki K, Tobe K: Adiponectin and adiponectin receptors in insulin resistance, diabetes, and the metabolic syndrome. J Clin Invest 2006, 116:1784-1792.

68. Hara K, Horikoshi M, Yamauchi T, Yago H, Miyazaki O, Ebinuma H, Imai Y, Nagai R, Kadowaki T: Measurement of the high-molecular weight form of adiponectin in plasma is useful for the prediction of insulin resistance and metabolic syndrome. Diabetes Care 2006, 29:1357-1362.

69. Kaser S, Tatarczyk T, Stadlmayr A, Ciardi C, Ress C, Tschoner A, Sandhofer A Paulweber B, Ebenbichler CF, Patsch JR: Effect of obesity and insulin sensitivity on adiponectin isoform distribution. Eur J Clin Invest 2008, 38:827-834

70. Brooks NL, Moore KS, Clark RD, Perfetti MT, Trent CM, Combs TP: Do low levels of circulating adiponectin represent a biomarker or just another risk factor for the metabolic syndrome? Diabetes Obes Metab 2007, 9:246-258.

71. Weiss R, Dufour S, Groszmann A, Petersen K, Dziura J, Taksali SE, Shulman G, Caprio S: Low adiponectin levels in adolescent obesity: a marker of increased intramyocellular lipid accumulation. J Clin Endocrinol Metab 2003, 88:2014-2018

72. Matsubara M: Plasma adiponectin decrease in women with nonalcoholic fatty liver. Endocr J 2004, 51:587-593.

73. Oranskiy SP, Yeliseyeva LN, Tsanaeva AV, Zaytseva NV: Body composition and serum levels of adiponectin, vascular endothelial growth factor, and interleukin- 6 in patients with rheumatoid arthritis. Croat Med J 2012, 53:350-356.

74. Lima Marcos M, Rosa Francisco J, Marín A, Romero-Vecchione E: Adiponectina y sus efectos pleiotrópicos en el sistema cardiovascular. Rev Venez Endocrinol Metab 2009, 7:3-9.

75. Shargorodsky M, Omelchenko E, Matas Z, Boaz M, Gavish D: Relation between augmentation index and adiponectin during one-year metformin treatment for nonalcoholic steatohepatosis: effects beyond glucose lowering? Cardiovasc Diabetol 2012, 11:61.

76. Kubota N, Terauchi Y, Yamauchi T, Kubota T, Moroi M, Matsui J, Eto K, Yamashita T, Kamon J, Satoh H, Yano W, Froguel P, Nagai R, Kimura S, Kadowaki T, Noda T: Disruption of adiponectin casues insulin resistance and neointimal formation. J Biol Chem 2002, 277:25863-25866.

77. Okamoto Y, Kihara S, Nishida M, Nishida M, Arita Y, Kumada M, Ohashi K, Sakai N, Shimomura I, Kobayashi H, Terasaka N, Inaba T, Funahashi T, Matsuzawa Y: Adiponectin reduces atherosclerosis in apolipoprotein E-deficient mice. Circulation 2002, 106:2767-2770.

78. Cnop M, Havel PJ, Utzschneider KM, Carr DB, Sinha MK, Boyko EJ, Retzlaff BM Knopp RH, Brunzell JD, Kahn SE: Relationship of adiponectin to body fat distribution, insulin sensitivity and plasma lipoproteins: evidence for independent roles of age and sex. Diabetologia 2003, 46:459-469.

79. Tschritter O, Fritsche A, Thamer C, Haap M, Shirkavand F, Rahe S, Staiger H, Maerker E, Häring H, Stumvoll M: Plasma adiponectin concentrations predict insulin sensitivity of both glucose and lipid metabolism. Diabetes 2003, 52:239-243.

80. Ouchi N, Kihara S, Arita Y, Maeda K, Kuriyama H, Okamoto Y, Hotta K Nishida M, Takahashi M, Nakamura T, Yamashita S, Funahashi T, Matsuzawa Y: Novel modulator for endothelial adhesion molecules: adipocyte-derived plasma protein adiponectin. Circulation 1999, 100:2473-2476.

81. Kumada M: Association of hypoadiponectinemia with coronary artery disease in men. Arterioscler Thromb Vasc Biol 2003, 23:85-89.

82. Pischon T, Girman CJ, Hotamisligil GS, Rifai N, Hu FB, Rimm EB: Plasma adiponectin levels and risk of myocardial infarction in men. JAMA 2004, 291:1730-1737.

83. Gil JS, Drager LF, Guerra-Riccio GM, Mostarda C, Irigoyen MC, Costa-Hong V, Bortolotto LA, Egan BM, Lopes HF: The impact of metabolic syndrome on metabolic, pro-inflammatory and prothrombotic markers according to the presence of high blood pressure criterion. Clinics (Sao Paulo) 2013, 68:1495-1501.

84. Ouchi N, Ohishi M, Kihara S, Funahashi T, Nakamura T, Nagaretani H, Kumada M, Ohashi K, Okamoto Y, Nishizawa H, Kishida K, Maeda N, Nagasawa A, Kobayashi H, Hiraoka H, Komai N, Kaibe M, Rakugi H, Ogihara T, Matsuzawa Y: Association of hypoadiponectinemia with impaired vasoreactivity. Hypertension 2003, 42:231-234.

85. Matsuzawa Y, Shimomura I, Kihara S, Funahashi T: Importance of adipocytokines in obesity-related diseases. Horm Res 2003, 60(Suppl 3):56-59.

86. Ouchi N, Kihara S, Arita Y, Okamoto Y, Maeda K, Kuriyama H, Hotta K, Nishida M, Takahashi M, Muraguchi M, Ohmoto Y, Nakamura T, Yamashita S, Funahashi T, Matsuzawa Y: Adiponectin, an adipocyte derived plasma protein, inhibits endothelial NF-êB signaling through a camp-dependent pathway. Circulation 2000, 102:1296-1301.

87. Okamoto Y, Arita Y, Nishida M, Muraguchi M, Ouchi N, Takahashi M, Igura T, Inui Y, Kihara S, Nakamura T, Yamashita S, Miyagawa J, Funahashi T, Matsuzawa Y: An adipocyte-derived plasma protein, adiponectin, adheres to injured vascular walls. Horm Metab Res 2000, 32:47-50.

88. Ouchi N, Kihara S, Arita Y, Nishida M, Matsuyama A, Okamoto Y, Ishigami M, Kuriyama H, Kishida K, Nishizawa H, Hotta K, Muraguchi M, Ohmoto Y, Yamashita S, Funahashi T, Matsuzawa Y: Adipocyte-derived plasma protein, adiponectin, suppresses lipid accumulation and class $A$ scavneger receptor expression in human monocyte-derived macrophages. Circulation 2001, 103:1057-1063.

89. Issan Y, Hochhauser E, Kornowski R, Leshem-Lev D, Lev E, Sharoni R, Vanella L, Puri N, Laniado-Schwartzman M, Abraham NG, Porat E: Endothelial progenitor cell function inversely correlates with long-term glucose control in diabetic patients: association with the attenuation of the heme oxygenase-adiponectin axis. Can J Cardiol 2012, 28:728-736

90. Sarkanen JR, Kaila V, Mannerström B, Räty S, Kuokkanen H, Miettinen S, Ylikomi T: Human adipose tissue extract induces angiogenesis and adipogenesis in vitro. Tissue Eng Part A 2012, 18(1-2):17-25.

91. Huang PH, Chen JS, Tsai HY, Chen YH, Lin FY, Leu HB, Wu TC, Lin SJ, Chen JW: Globular adiponectin improves high glucose-suppressed endothelial progenitor cell function through endothelial nitric oxide synthase dependent mechanisms. J Mol Cell Cardiol 2011, 51:109-119.

92. Zampetaki A, Kirton JP, Xu Q: Vascular repair by endothelial progenitor cells. Cardiovasc Res 2008, 78:413-421. 
93. Xu A, Wang Y, Lam KS, Vanhoutte PM: Vascular actions of adipokines molecular mechanisms and therapeutic implications. Adv Pharmacol 2010, 60:229-255.

94. Al-Attas OS, Hussain T, Al-Daghri NM, De Rosas E, Kazmi U, Vinodson B: The relationship between a Mediterranean diet and circulating adiponectin levels is influenced by cigarette smoking. J Atheroscler Thromb 2013, 20:313-320

95. Kawano J, Arora R: The role of adiponectin in obesity, diabetes, and cardiovascular disease. J Cardiometab Syndr 2009, 4:44-49.

96. Hotta K, Funahashi T, Arita Y, Takahashi M, Matsuda M, Okamoto Y, Iwahashi H, Kuriyama H, Ouchi N, Maeda K, Nishida M, Kihara S, Sakai N, Nakajima T, Hasegawa K, Muraguchi M, Ohmoto Y, Nakamura T, Yamashita S, Hanafusa T, Matsuzawa Y: Plasma concentrations of a novel, adipose-specific protein, adiponectin, in type 2 diabetic patients. Arterioscler Thromb Vasc Biol 2000, 20:1595-1599.

97. Balagopal P, George D, Yarandi H, Funanage V, Bayne E: Reversal of obesity-related hypoadiponectinemia by lifestyle intervention - a controlled randomized study in obese adolescents. J Clin Endocrinol Metab 2005, 90:6192-6197.

98. Monzillo LU, Hamdy O, Horton ES, Ledbury S, Mullooly C, Jarema C, Porter S, Ovalle K, Moussa A, Mantzoros CS: Effect of lifestyle modification on adipokine levels in obese subjects with insulin resistance. Obes Res 2003, 11:1048-1054

99. Kriketos AD, Gan SK, Poynten AM, Furler SM, Chisholm DJ, Campbell LV: Exercise increases adiponectin levels and insulin sensitivity in humans. Diabetes Care 2004, 27:629-630.

100. Silva FM, De Almeida JC, Feoli AM: Effect of diet on adiponectin levels in blood. Nutr Rev 2011, 69:599-612

101. Mantzoros CS, Williams CJ, Manson JE, Meigs JB, Hu FB: Adherence to the Mediterranean dietary pattern is positively associated with plasma adiponectin concentrations in diabetic women. Am J Clin Nutr 2006, 84:328-335.

102. Williams CJ, Fargnoli JL, Hwang JJ, Van Dam RM, Blackburn GL, Hu FB, Mantzoros CS: Coffee consumption is associated with higher plasma adiponectin concentrations in women with or without type 2 diabetes: a prospective cohort study. Diabetes Care 2008, 31:504-507.

103. Schmid PM, Resch M, Schach C, Birner C, Riegger GA, Luchner A, Endemann $\mathrm{DH}$ : Antidiabetic treatment restores adiponectin serum levels and APPL1 expression, but does not improve adiponectin-induced vasodilation and endothelial dysfunction in Zucker diabetic fatty rats. Cardiovasc Diabetol 2013, 12:46.

104. Yu JG, Javorschi S, Hevener AL, Kruszynska YT, Norman RA, Sinha M, Olefsky $J M$ : The effect of thiazolidinediones on plasma adiponectin levels in normal, obese, and type 2 diabetic subjects. Diabetes 2002, 51:2968-2974

105. Tripathy D, Clement SC, Schwenke DC, Banerji M, Bray GA, Buchanan TA, Gastaldelli A, Henry RR, Kitabchi AE, Mudaliar S, Ratner RE, Stentz FB, Musi N, Reaven PD, Defronzo RA: Baseline adiponectin levels do not influence the response to pioglitazone in ACT NOW. Diabetes Care 2014, Apr 4 [Epub ahead of print].

106. Lu CJ, Sun Y, Muo CH, Chen RC, Chen PC, Hsu CY: Risk of stroke with thiazolidinediones: a ten-year nationwide population-based cohort study. Cerebrovasc Dis 2013, 36:145-151.

107. Gallagher AM, Smeeth L, Seabroke S, Leufkens HG, Van Staa TP: Risk of death and cardiovascular outcomes with thiazolidinediones: a study with the general practice research database and secondary care data. PLoS One 2011, 6(12):e28157.

108. Tsunekawa T, Hayashi T, Suzuki Y, Matsui-Hirai H, Kano H, Fukatsu A, Nomura N, Miyazaki A, lguchi A: Plasma adiponectin plays an important role in improving insulin resistance with glimepiride in elderly type 2 diabetic subjects. Diabetes Care 2003, 26:285-289.

109. Tenenbaum A, Fisman EZ, Boyko V, Benderly M, Tanne D, Haim M, Matas Z, Motro M, Behar S: Attenuation of progression of insulin resistance in patients with coronary artery disease by bezafibrate. Arch Intern Med 2006, 166:737-741.

110. Tenenbaum H, Behar S, Boyko V, Adler Y, Fisman EZ, Tanne D, Lapidot M Schwammenthal E, Feinberg M, Matas Z, Motro M, Tenenbaum A: Long-term effect of bezafibrate on pancreatic beta-cell function and insulin resistance in patients with diabetes. Atherosclerosis 2007 194:265-271.
111. Hiuge A, Tenenbaum A, Maeda N, Benderly M, Kumada M, Fisman EZ, Tanne D, Matas Z, Hibuse T, Fujita K, Nishizawa H, Adler Y, Motro M, Kihara S, Shimomura I, Behar S, Funahashi T: Effects of peroxisome proliferator-activated receptor ligands, bezafibrate and fenofibrate, on adiponectin level. Arterioscler Thromb Vasc Biol 2007, 27:635-641.

112. Sahebkar A, Watts GF: Fibrate therapy and circulating adiponectin concentrations: a systematic review and meta-analysis of randomized placebo-controlled trials. Atherosclerosis 2013, 230:110-120.

113. Han SH, Quon MJ, Kim JA, Koh KK: Adiponectin and cardiovascular disease: response to therapeutic interventions. J Am Coll Cardiol 2007, 49:531-538.

114. Koh KK, Quon MJ, Han SH, Chung WJ, Lee Y, Shin EK: Anti-inflammatory and metabolic effects of candesartan in hypertensive patients. Int $J$ Cardiol 2006, 108:96-100.

115. Furuhashi M, Ura N, Higashiura K, Murakami H, Tanaka M, Moniwa N, Yoshida D, Shimamoto K: Blockade of the renin-angiotensin system increases adiponectin concentrations in patients with essential hypertension. Hypertension 2003, 42:76-81.

116. Guo Z, Zhang R, Li J, Xu G: Effect of telmisartan on the expression of adiponectin receptors and nicotinamide adenine dinucleotide phosphate oxidase in the heart and aorta in type 2 diabetic rats. Cardiovasc Diabetol 2012, 11:94.

117. Suzuki H, Sakamoto M, Hayashi T, luchi H, Ohashi K, Isaka T, Sakamoto N, Kayama Y, Tojo K, Yoshimura M, Utsunomiya K: Effects of co-administration of candesartan with pioglitazone on inflammatory parameters in hypertensive patients with type 2 diabetes mellitus: a preliminary report. Cardiovasc Diabetol 2013, 12:71.

118. Sharma AM, Janke J, Gorzelniak K, Engeli S, Luft FC: Angiotensin blockade prevents type 2 diabetes by formation of fat cells. Hypertension 2002, 40:609-611.

119. Schupp M, Janke J, Clasen R, Unger T, Kintscher U: Angiotensin type 1 receptor blockers induce peroxisome proliferators-activated- activity. Circulation 2004, 109:2054-2057.

120. Xu A, Wang H, Hoo RL, Sweeney G, Vanhoutte PM, Wang Y, Wu D, Chu W, Qin G, Lam KS: Selective elevation of adiponectin production by the natural compounds derived from a medicinal herb alleviates insulin resistance and glucose intolerance in obese mice. Endocrinology 2009, 150:625-633.

121. Hui X, Lam KS, Vanhoutte PM, Xu A: Adiponectin and cardiovascular health: an update. Br J Pharmacol 2012, 165:574-590.

122. Elkayam A, Peleg E, Grossman E, Shabtay Z, Sharabi Y: Effects of allicin on cardiovascular risk factors in spontaneously hypertensive rats. Isr Med Assoc J 2013, 15:170-173.

123. Ogawa $Y$, Kikuchi T, Nagasaki K, Hiura M, Tanaka Y, Uchiyama M: Usefulness of serum adiponectin level as a diagnostic marker of metabolic syndrome in obese Japanese children. Hypertens Res 2005, 28:51-57.

124. Tvarijonaviciute A, Martínez-Subiela S, Ceron JJ: Validation of 2 commercially available enzyme-linked immunosorbent assays for adiponectin determination in canine serum samples. Can J Vet Res 2010, 74:279-285.

125. Tremblay M, Loucif $Y$, Methot J, Brisson D, Gaudet D: Salivary pH as a marker of plasma adiponectin concentrations in women. Diabetol Metab Syndr 2012, 4:4.

126. Mamali I, Roupas ND, Armeni AK, Theodoropoulou A, Markou KB, Georgopoulos NA: Measurement of salivary resistin, visfatin and adiponectin levels. Peptides 2012, 33:120-124.

127. Thanakun S, Watanabe $H$, Thaweboon S, Izumi Y: An effective technique for the processing of saliva for the analysis of leptin and adiponectin. Peptides 2013, 47:60-65.

128. Jeon WS, Park JW, Lee N, Park SE, Rhee EJ, Lee WY, Oh KW, Park SW Park CY, Youn BS: Urinary adiponectin concentration is positively associated with micro- and macro-vascular complications. Cardiovasc Diabetol 2013, 12:137

129. Jung $\mathrm{CH}$, Kim BY, Kim CH, Kang SK, Jung SH, Mok JO: Association of serum adipocytokine levels with cardiac autonomic neuropathy in type 2 diabetic patients. Cardiovasc Diabetol 2012, 11:24.

130. Okamoto Y, Kihara S, Funahashi T, Matsuzawa Y, Libby P: Adiponectin: a key adipocytokine in metabolic syndrome. Clin Sci (Lond) 2006, 110:267-278.

131. Fisman EZ, Adler $Y$, Tenenbaum A: Biomarkers in cardiovascular diabetology: interleukins and matrixins. Adv Cardiol 2008, 45:44-64. 
132. Lin HV, Kim JY, Pocai A, Rossetti L, Shapiro L, Scherer PE, Accili D: Adiponectin resistance exacerbates insulin resistance in insulin receptor transgenic/knockout mice. Diabetes 2007, 56:1969-1976.

133. Okada-Iwabu M, Yamauchi T, Iwabu M, Honma T, Hamagami K, Matsuda K, Yamaguchi M, Tanabe H, Kimura-Someya T, Shirouzu M, Ogata H, Tokuyama K, Ueki K, Nagano T, Tanaka A, Yokoyama S, Kadowaki T: A small-molecule AdipoR agonist for type 2 diabetes and short life in obesity. Nature 2013, 503:493-499.

134. Parker-Duffen JL, Nakamura K, Silver M, Kikuchi R, Tigges U, Yoshida S, Denzel MS, Ranscht B, Walsh K: T-cadherin is essential for adiponectin-mediated revascularization. I Biol Chem 2013 288:24886-24897.

135. Parker-Duffen JL, Walsh K: Cardiometabolic effects of adiponectin. Best Pract Res Clin Endocrinol Metab 2014, 28:81-91.

136. Tyrberg B, Miles P, Azizian KT, Denzel MS, Nieves ML, Monosov EZ, Levine F, Ranscht B: T-cadherin (Cdh13) in association with pancreatic $\beta$-cell granules contributes to second phase insulin secretion. Islets 2011, 3:327-337.

137. Morisaki H, Yamanaka I, Iwai N, Miyamoto Y, Kokubo Y, Okamura T, Okayama A, Morisaki T: $\mathrm{CDH} 13$ gene coding T-cadherin influences variations in plasma adiponectin levels in the Japanese population. Hum Mutat 2012, 33:402-410

138. Danese E, Montagnana M, Sjögren M, Almgren P, Guidi GC, Hedblad B, Engström G, Lechi A, Minuz P, Melander O: A variant upstream of the $\mathrm{CDH} 13$ adiponectin receptor gene and metabolic syndrome in Swedes. Am J Cardiol 2011, 108:1432-1437.

139. Philippova M, Joshi MB, Pfaff D, Kyriakakis E, Maslova K, Erne P, Resink TJ: T-cadherin attenuates insulin-dependent signalling, eNOS activation, and angiogenesis in vascular endothelial cells. Cardiovasc Res 2012, 93:498-507.

140. Denzel MS, Scimia MC, Zumstein PM, Walsh K, Ruiz-Lozano P, Ranscht B: T-cadherin is critical for adiponectin-mediated cardioprotection in mice. J Clin Invest 2010, 120:4342-4352.

doi:10.1186/1475-2840-13-103

Cite this article as: Fisman and Tenenbaum: Adiponectin: a manifold therapeutic target for metabolic syndrome, diabetes, and coronary disease? Cardiovascular Diabetology 2014 13:103.

\section{Submit your next manuscript to BioMed Central and take full advantage of:}

- Convenient online submission

- Thorough peer review

- No space constraints or color figure charges

- Immediate publication on acceptance

- Inclusion in PubMed, CAS, Scopus and Google Scholar

- Research which is freely available for redistribution 